\title{
SOBRE HUIDOBRO Y NERUDA
}

En Chile son dos únicos poetas los que hoy por hoy representan la gestación de esta era iluminada: Vicente Huidobro y Pablo Neruda.

(Ariel, revista chilena de vanguardia, 1925)

Los nombres de Neruda y Huidobro han sido emparejados con un ritmo e intensidad casi obsesivos en los días del Simposio. En los trabajos leídos y en el diálogo mantenido sobre ellos se aludió una y otra vez a la enemistad que separó a estos dos grandes de la literatura hispánica contemporánea. Pero ¿cuándo y por qué se enemistaron?

Unos dicen que la rivalidad no se hizo notoria hasta mediados de 1935, cuando apareció en Santiago de Chile la epocal Antología de poesía chilena nueva, exigente crestomatía que incluyó solamente a diez poetas ${ }^{1}$ y que atribuyó la mayor importancia a Huidobro. Otros, rastreando los posibles orígenes de la animadversión, los sitúan a fines de 1934, cuando en la revista Pro se acusa a Neruda de haber plagiado a Tagore ${ }^{2}$. Pero la verdad es que en el primer caso, el de la Antología..., fue Pablo de Rokha y no Pablo Neruda quien se sintió menospreciado y lo manifestó con su acostumbrada acritud ${ }^{3}$. Y en el segundo caso, el del llamado «affaire Neruda-Tagore», fue Volodia Teitelboim y no Vicente Huidobro quien lanzó la primera piedra ${ }^{4}$. En enero de 1935, al recoger Huidobro

${ }^{1}$ Impresa por la Editorial Zig-Zag. Dio cabida a composiciones de tres poetas consagrados: Vicente Huidobro, Pablo de Rokha y Pablo Neruda, a las que siguen colaboraciones de Angel Cruchaga, Rosamel del Valle, Juvencio Valle, Humberto Díaz Casanueva, Omar Cáceres, Eduardo Anguita y Volodia Teitelboim.

2 «El affaire Neruda-Tagore», Pro, núm. 2 (noviembre de 1934).

${ }^{3}$ La Opinión, diario santiaguino, junio de 1935, fue el foro en que se ventiló la cólera del poeta manifestándose en forma de avalancha de cartas violentas de Pablo de Rokha contra Neruda, Huidobro y los otros antologizados.

4 Muy pronto, sin embargo, otros detractores de Neruda recogieron la acusación de Pro: en primer lugar, Pablo de Rokha («Esquema del plagiario», La Opi- 
en Vital (una revista ocasional de juguetona «higiene social») los documentos pertinentes al caso declaró que su único propósito era defenderse:

Publicado este plagio, se produce un fenómeno curioso en los circulillos de los compinches: gran indignación, furia (uterina). ¿Contra quién? ¿Contra Neruda por haber plagiado? ¿Contra Tagore por haber escrito diez años antes un poema bastante tonto y con las mismas ideas que iba a tener diez años después Pablo Neruda? No. La indignación va contra el que descubrió el plagio. Es el colmo. Y por no dejar de equivocarse, los compinches se enfurecen con Huidobro, que no tenía arte ni parte en el asunto. Es más colmo ${ }^{5}$.

Pero cualquiera que fuese la verdadera motivación original, el hecho es que hacia 1935 empezó a circular un extenso poema difamatorio contra Huidobro con el desafiante título de «Aquí estoy», y fue de inmediato atribuido a Neruda. Tal atribución vino a confirmarse en la conferencia dictada en 1936 por Arturo Aldunate Phillips en la Universidad de Chile sobre "El nuevo arte poético y Pablo Neruda», en la que dio a conocer algunos fragmentos del texto explicándolos brevemente:

A esta altura, y para juzgar de la originalidad y firmeza del poeta, para comprender la honradez de su masculinidad poética y de su modalidad expresiva, queremos referirnos a un poema inédito titulado «Aquí estoy».

Desgraciadamente, se trata de una composición que, por su índole personal, no puede ser dada a conocer totalmente y que, por el lenguaje crudo que en ella se emplea, debe quedar al margen de lo que puede publicarse. Sin embargo, recurrimos a este poema, porque es de un interés extraordinario para valorizar a Neruda. El poeta, puesto frente a frente de algunos de sus detractores, quienes, según él, han usado malas armas, deja brotar el caudal de su indignación y de su orgullo ${ }^{6}$.

El poema, aun en su forma expurgada, es extremadamente violento y no puede extrañar que tuviera inmediata y duradera repercusión, dentro

nión, 6 de diciembre de 1934); luego, Alfonso Toledo Rojas («Desenmascarando a Pablo Neruda», La Opinión, 10 de diciembre de 1934); seguidamente apareció un escrito bajo el seudónimo de «Justiciero», en el que se creyó ver a Vicente Huidobro («Pablo Neruda, plagiario o gran poeta», La Opinión, 15 de diciembre de 1934).

${ }^{5}$ Vital, núm. 2 (enero de 1935), p. 2.

- Arturo Aldunate Phillips, El nuevo arte poético y Pablo Neruda (Santiago: Nascimento, 1936), pp. 50-51. 
y fuera de Chile ${ }^{7}$. Uno de los primeros y más lamentables resultados fue que en los años cruciales de la lucha republicana en España y del Frente Popular en Chile, Huidobro y Neruda se encontraran situados en distintas posiciones dentro de la izquierda: uno, en el comunismo más militante $^{8}$, y el otro, en una suerte de antifascismo guerrero ${ }^{9}$. Hubo, desde luego, una Alianza de Intelectuales de Chile (nerudiana) en pugna con un Sindicato Profesional de Trabajadores Intelectuales de Chile (De Rokhahuidobriano). $\mathrm{Y}$ en Europa llegó a haber dos distintas delegaciones chilenas para ayudar a los refugiados españoles.

Tan tensa y contradictoria fue la situación en 1937 que, para poner término a la disputa, Tristan Tzara y otros intelectuales decidieron intervenir en nombre de la Association Internationale des Écrivains pour la Défense de la Culture. Enviaron la siguiente carta:

\section{A Vicente Huidobro.}

París, 1 de mayo de 1937.

Querido camarada y amigo:

Estamos seguros de interpretar el sentimiento no sólo de todos los escritores hispanoamericanos, sino el de los antifascistas del mundo entero, al decirte que delante de la espantosa tragedia que aflige al pueblo español deploraríamos que pudieran seguir existiendo motivos de discordia entre tú y el camarada Pablo Neruda, luchadores ambos de la misma causa.

${ }^{7} \mathrm{He}$ visto varias copias a máquina del poema entero, que consta de unas 230 líneas: una en el archivo de Armando Donoso en el ex Instituto de Literatura Chilena y otra en la «Colección Neruda» Suny Library (Stony Brook, Nueva York). Ultimamente he podido ver una versión impresa cuyo dudoso colofón reza: «Este poema de Pablo Neruda, titulado Aqui estoy, con viñetas dibujadas por Ramón Gaya, fue impreso por amigos del poeta en la ciudad de París, durante el año de 1938».

${ }^{8}$ Huidobro ingresó en el Partido Comunista en los años veinte, y durante la década de los treinta insistió en que otros escritores e intelectuales ingresaran también. En una entrevista de 1933 hace la siguiente observación tajante: «Para mí, todo individuo menor de sesenta años que no es simpatizante al comunismo es un mediocre o un señor que vive fuera de la vida, y todo individuo menor de cuarenta años que no es comunista es un idiota» (Síntesis, I, 2 [abril de 1933], p. 4).

${ }^{9}$ Neruda, como es sabido, no ingresó en el Partido Comunista hasta 1945. Antes abogaba por una izquierda independiente. En 1937 lo encontramos enunciando lo siguiente: "Yo no soy comunista. Ni socialista. Ni nada. Soy simplemente escritor. Escritor libre que ama la libertad con sencillez. Amo al pueblo. Pertenezco a él porque de él vengo. Por ello soy antifascista. Mi adhesión al pueblo no peca de ortodoxia ni de sometimientos (Ercilla, 2 de noviembre de 1937, p. 11). 
En atención a lo que las personas de cada uno de Uds. representa queremos pedirles, pues, que a partir de hoy den Uds. el alto ejemplo de olvidar cualquier motivo de resentimiento y división que haya podido existir entre ambos para que con entusiasmo acrecido y dentro de una sola voluntad militemos todos bajo la bandera del pueblo víctima por el triunfo material y moral sobre el fascismo.

Agradeciéndote en nombre de ese pueblo español el gesto que de ti aguardamos te saludamos con fraternal cordialidad.

(Firmas de Tristan Tzara, José Bergamín, Gonzalo More, Eudocio Rabines, Alejo Carpentier, César Vallejo, Leonardo López, Juan Larrea, Renato Leduc, F. Pita Rodríguez, Andrés Iduarte.)

Idéntica carta fue enviada a Neruda ${ }^{10}$.

A estas alturas, después de tantos años, y desaparecidos los antagonistas, no tendría sentido resucitar la antigua querella, que, además, carecía totalmente de lógica; pues difícil, si no imposible, sería atribuirle la lógica estética de otra polémica ya clásica en nuestra historia literaria (Góngora y Quevedo). Por eso, en esta breve posdata quiero destacar otros textos pertinentes, pero de distinto orden de preferencias, y no para reanimar la vieja y sin duda estéril disputa, sino para facilitar el conocimiento total de la trayectoria seguida por la relación Neruda-Huidobro, trayectoria en que la polémica gravita sólo tangencialmente.

El escrito más temprano de Neruda sobre Huidobro que he podido localizar data de 1924 y se titula, de manera premonitoria, «Defensa de Vicente Huidobro». Es una breve nota redactada para acompañar un poema de Huidobro («Automne régulier») en Claridad, revista anarquista de la Federación de Estudiantes de la Universidad de Chile. Quienes vean el número de la revista, correspondiente a junio de 1924, toparán con una coincidencia algo irónica: en la misma página que incluye los textos de Huidobro y Neruda figura también un escrito de Pablo de Rokha. Así es como los tres grandes de la literatura chilena se compaginaban entonces en amistosa fraternidad. Esto, en 1924, en plena vanguardia:

\section{Defensa de Vicente Huidobro}

Su poesía extrañamente transparente, ingeniosamente ingenua. Con esa pureza del viejo lied del Norte, motivo desnudo, de realización

${ }^{10}$ La carta está reproducida en Juan Larrea, Del surrealismo a Machupicchu (México: Mortiz, 1967). 
acuaria. Creación, creacionismo, estética nueva, todo eso es fórmula, garabatos, ropa usada. Lo único es el poeta y el camino desde él a su poema. Huidobro, qué fresca sensación infantil, de juego atrevido, mezcla del extático hay-kay con el trepidante traqueteo del Occidente.

Otro texto significativo de Neruda sobre Huidobro, de gran interés documental, es de 1968. Se titula «Búsqueda de Vicente Huidobro». Escrito para la revista Ercilla ( 7 de febrero de 1968) en el vigésimo aniversario de la muerte del adversario, es una especie de palinodia, o más bien de reconocimiento público del alto valor literario de Huidobro, así como un lamento por las circunstancias públicas y personales que impidieron un mayor acercamiento intelectual entre ellos:

\section{Búsqueda de Vicente Huidobro}

Me cuentan que en estos días han pasado veinte años desde la muerte de Vicente Huidobro.

Yo no lo sabía. Nunca fui amigo de él. Y la vida literaria nos separó con crueldad.

Creo que se hace imperioso mi deber hacia su poesía.

Lo que más me sorprende en su obra releída es su diafanidad. Este poeta literario, que siguió todas las modas de una época enmarañada y que se propuso desoír la solemnidad de la naturaleza, deja pasar a través de su poesía un constante canto de agua, un rumor de aire y hojas y una grave humanidad que se apodera por completo de sus penúltimos y últimos poemas.

Desde los encantadores artificios de su poesía afrancesada hasta las poderosas fuerzas de sus versos fundamentales, hay en Huidobro la lucha entre el juego y el fuego, entre la evasión y la inmolación. Esta lucha constituye un espectáculo: se realiza a plena luz y casi a plena conciencia, con una claridad deslumbradora. Considero a Vicente Huidobro como un poeta clásico de nuestro idioma, y nos embarga esta corriente que no tiene desenlace, esta corriente inacabable de claridad. No hay poesía tan clara como la poesía de Vicente Huidobro.

Así como la mayoría de su prosa peca de su persona, de su juguetón personalismo, su obra poética es un espejo en el que se suceden las imágenes de la delicia pura o el juego de su propio sacrificio. Porque a mí me parece que Huidobro se consumió en su propio juego y en su propio fuego. A pesar de que su inteligencia poética es la clave de su brillo, tuvo tal predilección por forjarse un anecdotario personal que terminó por abrumarlo y sepultarlo. Por suerte, su poesía salvará su recuerdo, recuerdo que seguirá creciendo en profundidad y en espacio. 
La originalidad preocupó al poeta Huidobro en forma obsesionante durante su vida. Una originalidad de existencia y de pensamiento. Sin embargo, aquietados los rumores de su época, no serán tales prendas las que lo distingan. Esta preocupación lleva a menudo a los escritores a convertirse en la caricatura de sí mismos. Releyendo a Huidobro nos damos cuenta de que sus posiciones arrogantes, al desaparecer con su vida, no quebrantaron su transparencia. Multitud de sus versos siguen teniendo una frescura que parecían no tener, porque nacieron tal vez como elaborados por la inteligencia. Ahora vemos rocío en ellos, como si fueran hierbas matinales.

Mucho nos debe preocupar que un poeta de su dimensión y de su calidad se afirme en el patrimonio nacional. Yo he propuesto un monumento para él, junto a Rubén Darío, pero nuestros gobiernos son parcos en erigir estatuas a los creadores y pródigos en monumentos sin sentido.

No podríamos pensar en Huidobro como un protagonista político, a pesar de sus veloces incursiones en el predio civil. Tuvo hacia las ideas inconsecuencias de niño mimado. Pero todo esto quedó atrás en la polvareda, y seríamos inconsecuentes nosotros mismos si comenzáramos a clavarlo con alfileres a riesgo de menoscabar sus alas.

Sin embargo, para mí, sus poemas a la Revolución de Octubre y a la muerte de Lenin son parte fundamental de la contribución de Huidobro al gran despertar humano.

En sus últimos años Huidobro trató de reanudar y mejorar la relación que tuvimos brevemente cuando recién volvió por primera vez de Europa. Yo, herido por las incidencias de la guerrilla literaria, no acepté esta aproximación. Me he arrepentido muchas veces de mi intransigencia. Cargo con mis defectos provincianos como cualquier mortal. No me encontré con él en esos días, no lo encontré después. Desde entonces sólo he continuado el diálogo con su poesía.

Diálogo fructífero, ya que cinco años después, y en el umbral de su propia muerte, Neruda se sintió obligado a redactar otra página sobre el recordado poeta creacionista. Se titula simplemente «Vicente Huidobro» y apareció en 1974 como prólogo póstumo a una recopilación de textos franceses de Huidobro que hizo el poeta belga Fernand Verhesen para una editorial parisiense:

\section{Vicente Huidobro}

Ver a Vicente Huidobro desde Bruselas, con Plaza Mayor, con Santa Gúdula, entre el herbario de la poesía francesa y flamenca, es otra cosa que verlo desde Chile, su patria antártica, aislada de todos los mundos por cordilleras y océanos. 
Para ustedes, Huidobro es parte del follaje, del crecimiento. Para nosotros, chilenos, Huidobro es acercamiento, relación, viaje.

Huidobro, como Rubén Darío antes, es un importador de tendencias, de construcciones, de fragancias compuestas en el fuego central de la Europa de la primera guerra mundial. Apollinaire, Juan Gris y el cubismo, el Ballet Ruso, desatan una nueva rosa de los vientos y nuestro Huidobro es el primer americano que mira donde va la flecha, siente crecer la rosa en sus propias manos. No digo en su corazón: Huidobro es un artesano, arquitecto del castillo en el aire, orfebre empeñado en la alquimia. Su mundo mágico tiene la insistencia y el movimiento de una repetición manual: su destreza es la del maravilloso malabarista: sus relámpagos son producidos por un ejercicio voltaico nunca interrumpido.

Rubén Darío, sin dejar de ser un americano fundamental, un indio melancólico, nos abrió las puertas del gran modernismo: trajo a América la suave ceniza de Verlaine y alcanzó a enfrentarnos al coloquio de Laforgue y al aullido de Lautréamont. Vicente Huidobro se saturó de la elegancia cubista y alcanzó a divisar, dentro de su humanismo interplanetario, la cabellera surrealista que iba a flotar hasta ahora sobre el océano Atlántico, como las algas flotadoras.

La poesía chilena fue fundada en el siglo xvi por un conquistador español, paje de Carlos V, llamado Alonso de Ercilla. El joven soldado, perdido en la selva sangrienta de la guerra, reveló al mundo la proeza araucana. Mucha sangre perdió el Imperio español en aquella guerra que duró tres siglos.

Ercilla celebró más a los invadidos que a los invasores. La poesía de Chile emergió como una flor roja del combate de una raza que quedó diezmada sin rendirse ante el formidable enemigo. Desde entonces este pequeño país ha tenido voz propia. $Y$ esta voz se oye entre la nieve andina y las ilimitadas espumas del gran océano.

Parte considerable de esta voz, de este luminoso castillo levantado en nuestras soledades, es el canto creador, inventivo, juguetón y fantástico de Vicente Huidobro.

Este juego sostenido, que como un surtidor al parecer inagotable levanta en su torre de cristal un círculo de esplendor y de alegría, es la obra del poeta chileno que es hoy honrado por la antigua y nueva cultura de Bélgica en esta edición.

Con placer y con honor he escrito estas palabras para festejar este acontecimiento, agradecerlo a los poetas belgas y saludar la memoria de mi compañero desaparecido cuando se levanta, esta vez muy lejos de Chile, el resplandor de su poesía ${ }^{11}$.

${ }^{11}$ Le Citoyen de l'oubli [El ciudadano del olvido y otros textos] (Paris: Éditions Saint-Germain-des Près, 1974), pp. 9-10. 
Es un testimonio de definitiva reconciliación, admirable por su limpidez y nobleza, la nobleza de un gran poeta movido por el resplandor de la auténtica poesía. Pues, como dijera la revista Ariel en 1925, en plena vanguardia: «Son dos únicos poetas los que hoy por hoy representan la gestación de esta era iluminada: Vicente Huidobro y Pablo Neruda».

The University of Chicago.

RENÉ DE CosTA 